\title{
Maratona Atenas 2004: A (Re)Categorização em Textos Jornalísticos
}

(The 2004 Athens Marathon: The (Re)categorization in Media Texts)

\author{
Milton Francisco ${ }^{1}$ \\ (Universidade Federal do Acre)
}

RESUMO: O processo de referenciação implica (re) categorizar os objetos discursivamente (cf. Mondada 1997; Mondada e Dubois 2003). Este artigo consiste em uma reflexão epistemológica sobre processo de (re) categorização, voltando-se para o procedimento do enunciador ao referir e (re) categorizar os objetos. Focaliza-se a (re) avaliação que os objetos podem ter a cada designação. Esse processo é analisado em textos jornalísticos escritos de caráter informativo e opinativo, os quais têm como tema o episódio atípico ocorrido com o atleta brasileiro Vanderlei Cordeiro de Lima na prova de Maratona dos Jogos Olímpicos de Atenas, em 2004. Os resultados apontam que, no texto informativo, em geral o ponto de vista e valores atribuídos, por exemplo, ao episódio e a Vanderlei, originam-se de discurso albeio, enquanto que, no texto opinativo, o autor geralmente mescla seu ponto de vista e valores com os do discurso alheio. Em ambos os tipos de texto, prevalece grande diversidade de categorias, a qual corresponde à heterogeneidade semântico-referencial dos textos.

PALAVRAS-CHAVE: referenciação; (re)categorização; texto jornalístico; Maratona Atenas 2004.

ABSTRACT: The process of referentiation implies (re) categorizing the objects discursively (Mondada 1997; Mondada and Dubois 2003). This article is an epistemo logical reflection about the process of (re) categorization, focusing at the enunciator's procedure when referring and (re)categorizing objects. It's focused the (re)evaluation that the objects can have in each designation. This process is analyzed in written media infor-

\footnotetext{
1 Agradeço à Profa. Dra. Iara Bemquerer Costa, da Universidade Federal do Paraná, pelas contribuições durante orientação de mestrado, as quais procuro trazer para o presente texto. Agradeço também ao Prof. Alberto Gonçalves, pela gentileza no abstract, e ao Prof. Dr. Humberto Espeleta, da Universidade Federal do Acre, pela leitura e contribuições na versão final deste texto. As falhas que, aqui, insistem permanecer são todas minhas. Contato: miltonchico@yahoo.com.br
}

D.E.L.T.A., 23:2, 2007 (167-202) 
mative and opinion texts whose topic is the odd episode that happened to the Brazilian athlete Vanderlei Cordeiro de Lima during the marathon competition at the Olympic Games in Athens, in 2004. The results show that in informative texts, in general, point of view and attributed values, for example, to the episode and to Vanderlei, originated from a third person; whereas in opinion texts, the author usually mixes his/her point of view and values with the ones of a third person's. In both sorts of text it prevails a great diversity of categories, which corresponds to the semantic-referential heterogeneity in the texts.

KEY-WORDS: referentiation; (re)categorization; media text; Marathon Athens 2004.

\section{Considerações iniciais}

O espírito olímpico...

O espírito de porco...

Para o estudo da referenciação, Mondada e Dubois (2003) consideram como questão relevante a construção de categorias, as quais, assim como os referentes, são constituídas no âmbito do texto. A categorização é um processo que se dá a partir de propriedades do referente, de modo a atividade de categorizá-lo ser entendida como escolha de uma de suas propriedades que o autor faz no ato de designação. Em síntese, a categoria é um agrupamento de referentes/objetos realizado a partir de determinada propriedade que possuem em comum.

Este trabalho objetiva refletir sobre aspectos teóricos do processo de (re)categorização, procurando identificar e compreender particularidades desse processo no texto escrito jornalístico de caráter informativo e opinativo, especialmente aquelas concernentes ao procedimento do autor ao referir e (re)categorizar os objetos referidos, e aquelas concernentes aos valores que o autor atribui a esses objetos.

Para composição do corpus, assume-se como critério principal o aspecto temático dos textos: o episódio atípico ocorrido durante a prova de Maratona dos Jogos Olímpicos de 2004, realizados em Atenas, na Grécia, em que o maratonista brasileiro Vanderlei Cordeiro de Lima (doravante VCL) foi interceptado pelo irlandês Cornelius Neil Horan (doravante $\mathrm{CNH}$ ). Aqui, elegem-se para reflexão os principais referentes constituintes do tema 
dos textos selecionados, a saber, o incidente, VCL e CNH. O corpus compõe-se de textos coletados do Jornal Estado de Minas e das revistas semanais Veja e Isto é, os quais, neste estudo, são categorizados de um modo geral como textos jornalísticos informativos ou opinativos. Mas, comumente, são tratados como notícia, reportagem, artigo assinado, editorial, crônica, charge.

Considerando que o processo de referenciação implica a possibilidade de (re)agrupar, de (re)categorizar o(s) referente(s) discursivamente, e tendo em conta que eleger determinada propriedade ${ }^{2}$ do referente é posicionarse frente a ele, a hipótese aqui é a de que o ponto de vista e a avaliação dos interlocutores (entendidos como autor e leitor, visto que o autor pressupõe e orienta-se também pela visão e valores de seus leitores em potencial) também condicionem e integrem o processo de categorização de objetos. Ou seja, qualquer ponto de vista/avaliação pode integrar a construção (e categorização) de objetos de discurso, em conformidade com a postura assumida pelo autor em relação ao objeto designado (coisa, indivíduo, evento). Quanto à identificação desse provável ponto de vista/avaliação, ela ocorre, neste estudo, especialmente a partir da composição/formação lingüística dos sintagmas nominais empregados na designação referencial.

Outra hipótese é a de que, a partir do incidente/episódio ocorrido na Maratona, a comunidade em geral passa a atribuir, tanto a VCL, quanto a $\mathrm{CNH}$, propriedades novas, as quais não lhes faziam parte anteriormente. A atribuição dessas propriedades implica, sobretudo, que ambos são categorizados sob categorias até então estranhas a eles, e, em princípio, designados por meio de SNs relativamente novos. Por certo, atribuir-lhes propriedades novas é reavaliá-los socialmente, é apresentar ponto de vista "inédito" a respeito de ambos, é assumir posição socioideológica, também nova, em relação a eles. Na linha desse raciocínio, na análise a se desenvolver, atenta-se para a postura - em face do incidente, VCL e CNH - dos autores dos textos que compõem o corpus deste estudo. A motivação para esse procedimento, em parte, surge das palavras de Mondada e Dubois (2003: 25): "a variação e a concorrência categorial emergem notadamente quando uma cena é vista de diferentes perspectivas, que implicam diferen-

\footnotetext{
2 O termo propriedade é empregado de modo genérico, ele envolve atributos do referente atribuídos pelo autor, princípio, ação, atitude, característica, aspecto, "parte" do objeto referido.
} 
tes categorizações da situação, dos atores e dos fatos", e das coisas integrantes da cena em questão ${ }^{3}$.

\section{Referenciação: construindo referentes discursivamente}

Na perspectiva do presente estudo, a referência diz respeito a um processo caracterizado por instabilidade em relação à língua - em que os itens lexicais são trabalhados em dado texto - e em relação ao ponto de vista e avaliação dos interlocutores sobre os objetos referidos. Dá-se dentro do texto um processo em que o referente, uma vez introduzido, pode ser reativado, revisto, redirecionado, fragmentado ou enriquecido, repensado e redefinido durante a construção textual. Assim sendo, cada referente é delineado e "construído" de modo bastante particular segundo sua inserção e desenvolvimento no discurso. Com isso, a referência ganha um caráter de textualidade que revela dinamicidade e instabilidade, de modo a compreender os referentes como construção discursiva. Tem-se uma referência discursiva, entendida como representação mental - mediante uso de expressões lingüísticas - de objetos, indivíduos e eventos no âmbito do texto. Para nomear esse processo, em vez de empregar-se a noção de referência, emprega-se a de referenciação, apoiando-se especialmente em Mondada e Dubois (2003).

Mondada e Dubois sugerem substituir o termo referência - termo corrente em estudos em Lingüística Textual, por exemplo - por referenciaçãa, visto que esse termo pode expressar o processo de progressão referencial constituído ao longo do texto de forma situada, além de expressar a dinamicidade e diversidade referencial presente no discurso. De acordo com as autoras, a prática de designar objetos (coisas, eventos, indivíduos) conduz à construção discursiva de referentes na intersubjetividade das interações verbais. Assim, os referentes são denominados objetos de discurso.

Os objetos de discurso são construção discursiva, que se dá de forma situada, única, cognitiva, no âmbito do discurso, quando da interação sócioverbal. Eles dizem respeito à instabilidade das expressões lingüísticas em

\footnotetext{
3 Embora, neste artigo, dedique atenção ao texto escrito e faz-se referência a autor como produtor do texto, deve-se ter em conta que, em princípio, o suporte teórico levado em conta diz respeito tanto à fala quanto à escrita.
} 
relação ao mundo da realidade - mas também devido à carga semânticoreferencial com que essas expressões são empregadas -, dizem respeito à plasticidade dos objetos referidos, à alteração dos objetos ao longo do texto, ao trabalho cognitivo dos interlocutores. São esses objetos discursivos que os itens lexicais vão designar, e não propriamente algo localizado fora da mente e do texto, como bem atentam Koch e Marcuschi (1998). A despeito de os referentes serem "manuseados" discursivamente, entendese aqui que uma relação palavra-mundo é estabelecida, no sentido de os objetos do mundo serem o ponto de partida e a motivação para a produção textual, sem que o uso das palavras, contudo, diga respeito a qualquer relação estável, única ou direta com o mundo. O que ocorre é uma relação referencial instável e múltipla, em especial devido à visão e valores que os interlocutores têm do mundo, às alterações físico-químicas ou ético-morais que os objetos sofrem, ao papel que assume o autor nas relações sociais e em cada discurso.

Os objetos de discurso não são compreendidos como entidades estáticas que, uma vez inseridas no texto, cristalizam-se, e sim, como entidades dinâmicas, que, em geral, ao longo do texto são reativadas, revistas, redirecionadas, fragmentadas, enriquecidas mediante o uso de diferentes formas lingüísticas, submetidas a diferentes fatores contextuais e a diferentes pontos de vista e valores. Isto é, o referente pode ser "repensado" e "redefinido" no desenrolar da produção textual, ocasionando, assim, um processo dinâmico denominado progressão referencial.

Didaticamente, a progressão referencial pode ser pensada, tanto acerca de um só referente - neste caso, as expressões que designam o referente seriam correferenciais -, quanto de vários referentes, os quais estabeleçam alguma relação semântico-referencial.

$\mathrm{Na}$ progressão referencial, leva-se em conta a carga semântico-referencial prévia de cada item lexical que serve de designação, como também fatores discursivos e cognitivos particulares a cada texto, os quais parecem fornecer grande contribuição para que o referente se constitua de modo bastante particular em dada situação sócio-verbal. Em outros termos, conhecer um sistema lingüístico é basilar, mas ele não é tudo, porque, no processo referencial constituinte do texto, os indivíduos aproveitam também de inferências - informações implicitadas e instauradas pelo cotexto -, do conhecimento de mundo armazenado na mente, do conhecimento compartilhado, do contexto situacional e sócio-histórico. 
O processo de referenciação implica pensar as formas lingüísticas empregadas para designar os objetos, pois formas distintas ativam sentidos distintos, cada forma lingüística ativa uma carga semântico-referencial particular. A seção seguinte é dedicada à composição dos sintagmas nominais, o que também diz respeito à metodologia empregada neste estudo.

\section{A composição de Sintagmas Nominais}

O processo de referenciação e o de categorização configuram-se nas designações lingüísticas inseridas na superfície do texto, particularmente as caracterizadas como sintagma nominal (SN). Considera-se, aqui, a partir de Marcuschi e Koch (2002), que o SN pode apresentar-se com as seguintes formações:

- Nome (nome-núcleo);

- Determinante + Nome;

- Nome + Modificador(es);

- Determinante + Nome + Modificador(es);

- Determinante + Modificador(es) + Nome;

- Determinante + Modificador(es) + Nome + Modificador(es).

Entende-se determinante como artigo definido ou indefinido, numeral, e pronome possessivo, indefinido ou demonstrativo; e modificador como adjetivo, advérbio, sintagma preposicionado ou oração relativa. Em outros termos, o $\mathrm{SN}$ pode ser de caráter nominal, advérbio-nominal, verbonominal.

Observe-se que, para o presente estudo, não se considera o pronome como espécie de SN, em parte devido a sua particularidade de não-autonomia semântica. Isto é, $\mathrm{SN}$ envolve forma nominal (nova ou repetida). Desse modo, aqui a categoria $\mathrm{SN}$ difere, por exemplo, da representação que tem o SN em diagramas arbóreos, em que a forma pronominal pode ser classificada como SN.

Os SNs, por vezes, se iniciam por preposição. Ocorre combinação entre uma preposição e o determinante. Por exemplo: do maratonista brasileiro (do 
$=\mathrm{de}+\mathrm{o})$; desse sujeito irlandês (desse $=\mathrm{de}+\mathrm{esse})$; naquela prova de maratona que marcou (naquela $=\mathrm{em}+$ aquela); pela medalha de ouro $($ pela $=$ per + a). Acerca desses casos, embora sejam pouco freqüentes no corpus do presente estudo, opta-se por considerar a preposição como componente do SN. Entretanto, não se refletirá sobre a influência semântico-referencial que essa preposição talvez exerça sobre os SNs.

A composição lingüística dos SNs é relevante ao processo de referenciação e ao de (re)categorização, pois um novo SN empregado pode ativar determinada(s) propriedade(s) do objeto de discurso, submetendo-o a uma ou a outra categoria. E ainda, a escolha do determinante e do modificador do nome-núcleo parece ser um recurso com que o autor imprime seu ponto de vista e valores no objeto em questão. Por exemplo, $\mathrm{CNH}$ pode ser designado por um pobre cidadão de saia vermelh $a^{4}$ ou esse homem que tirou nosso ouro. Em ambos os SNs, parece que a avaliação/ponto de vista é expressa pelos determinantes e pelos modificadores dos nome-núcleos (cidadão e homem). Observe-se que o determinante esse revela depreciação do objeto, enquanto um é relativamente neutro quanto ao aspecto semântico. O modificador pobre sugere que $\mathrm{CNH}$ é "fraco" espiritual e ético-moralmente; de saia vermelha revela certa atribuição pejorativa a $\mathrm{CNH}$; e que roubou nosso ouro culpa $\mathrm{CNH}$ por impedir VCL de ser o primeiro colocado na maratona e trazer a medalha de ouro para o Brasil, a qual, em tese, pertenceria a todos os brasileiros. Ainda sobre de saia vermelha, o aspecto pejorativo sugerido vincula-se, de certo modo, a um falante/autor hipotético que desconhece a peça predominantemente vermelha do traje de $\mathrm{CNH}$, e, por conseguinte, seu significado na cultura escocesa. Caso o falante/autor conhecesse o que representa um kilt e seu uso nessa cultura, a análise que se faria é de que há avaliação sim, a expressão revelaria sarcasmo do falante/ autor.

A despeito da relevância dos determinantes e modificadores nessas duas designações, o nome-núcleo também pode "representar" a avaliação do autor sobre o objeto referido. Por exemplo, nos SNs esse senhor irlandês e esse louco irlandês, em princípio, senhor condiz com avaliação positiva, en-

\footnotetext{
4 Ao longo desta reflexão teórica, além dos excertos de textos jornalísticos componentes do corpus, que serão identificados como tais, inserem-se seqüências de SNs hipotéticas, também concernentes à Maratona dos Jogos Olímpicos de Atenas 2004, as quais não são extraídas necessariamente do corpus, e sim constituídas exclusivamente para este estudo.
} 
quanto louco com avaliação negativa, independentemente de ambos os SNs designarem o mesmo objeto. Essa breve reflexão não leva em conta a hipótese de senhor ser enunciado ironicamente, o que inverteria a avaliação para negativa.

No corpus do presente estudo, são freqüentes casos em que, no modificador - sobretudo sintagma preposicionado e oração relativa -, há nome que ativa objeto diferente do ativado pelo nome-núcleo, tal como ocorre com os SNs um pobre cidadão de saia vermelha e esse homem que tirou nosso ouro. Os nomes saia e ouro ativam objetos que contribuem na construção da carga semântico-referencial de seus respectivos nomes-núcleos. Por razões metodológicas, cabe deixar claro como os SNs assim constituídos são tratados ao longo deste estudo, particularmente designações que envolvam VCL, CNH e o episódio provocado por $\mathrm{CNH}$. Observe-se:

\section{Excerto 1 \\ "Paranaense é bronze na maratona, mesmo após ser trombado por manifestante que já havia prejudicado GP de F-1 em 2003" (Vanderlei é exemplo de elegância e superação. Texto informativo, EM, CO, 30/8/04, p.31) ${ }^{5}$.}

O SN destacado refere-se a $\mathrm{CNH}$. O emprego de manifestante como nome-núcleo seria o suficiente para designá-lo, considerando conhecimento sobre o episódio. Mas o autor preferiu modificar (com oração relativa) o nome-núcleo, caracterizando o referente com outro episódio também provocado por $\mathrm{CNH}$ numa determinada prova de Fórmula 1. Esse modificador, além de novo episódio, ativa, com o nome GP de F-1, um objeto distinto do ativado pelo nome-núcleo, de modo que dois objetos secundários integram a construção discursiva do objeto principal - $\mathrm{CNH}$. Aliás, o episódio ativado por esse modificador é lembrado em vários textos do corpus, certamente devido à semelhança ético-moral com o episódio da maratona.

Ocorrem casos também em que VCL, CNH ou o episódio/incidente não se caracterizam como nome-núcleo, mas como modificador. Exemplo disso é o SN destacado abaixo.

\footnotetext{
5 Ao final de cada excerto, faz-se sua identificação, inserindo o título do texto, o jornal ou revista, o caderno ou seção, a data e a página de publicação. Códigos: EM: Estado de Minas, CO: Caderno Olimpíadas.
} 


\section{Excerto 2}

Além do reconhecimento do povo, ele ganhou $\mathrm{R} \$ 200$ mil destinados pela empresa aos seus atletas campeões olímpicos. O normal seria ele receber $\mathrm{R} \$ 70$ mil pelo bronze, mas o patrocinador reconheceu o esforço do brasileiro e o recompensou com o prêmio destinado aos medalhistas de ouro. (Recepção de ouro. Texto informativo. EM, SE, 02/9/04, p.29) ${ }^{6}$

O nome-núcleo de o esforço do brasileiro refere-se à vontade de vencer de VCL, mesmo ante a intercepção de CNH. O modificador refere-se a VCL. Em ocorrências assim, parece que o objeto de discurso referido - vale enfatizar, pelo nome-núcleo sobretudo - tende a ser uma espécie de característica de VCL, de CNH ou do episódio.

Embora o interesse neste estudo volte-se para os três referentes - VCL, $\mathrm{CNH}$ e o incidente -, o procedimento metodológico aqui está em considerar os SNs por inteiro. Isto é, considera-se o SN que tem um dos três referentes como nome-núcleo - podendo ter ou não outro objeto introduzido como modificador, como se viu no excerto $1-$, como também considera-se o SN que tem um dos três referentes como modificador de um nome-núcleo que se refere a um outro objeto.

Em síntese, embora, aparentemente, um mesmo SN possa ativar objetos distintos, o objeto de fato designado - e apenas ele - é o objeto ativado pelo nome-núcleo. Em o esforço do brasileiro, por exemplo, a palavra esforço é a principal na designação do referente.

A preocupação na seção seguinte é com o procedimento do autor, do texto jornalístico em particular, no que tange à escolha de propriedades dos objetos ao designá-los. Focaliza-se a categorização, a construção de categorias.

\section{Categoria: agrupamento discursivo de objetos}

Inicialmente, pode indagar-se o que é uma categoria. Categoria é um grupo de objetos (coisas, eventos, indivíduos) agrupados a partir de uma propriedade, atributo, aspecto, condição ou atividade comum a todos. Uma

${ }^{6}$ Código: SE: Seção de Esportes. 
noção básica de categoria é identificada nas palavras de Lyons (1980, p.129): "por classe ${ }^{7}[\ldots .$.$] entende-se qualquer colecção de indivíduos independen-$ temente do princípio que permitiu juntá-los como membros dessa classe". Por exemplo, os melhores maratoristas brasileiros (categoria A) e os atletas participantes da maratona $x$ (categoria B), sendo que: para o agrupamento de A, orienta-se pela propriedade/princípio que diz respeito à nacionalidade dos referidos atletas, enquanto, para B, pela propriedade/princípio que diz respeito à presença de determinados atletas em determinada prova de atletismo. Considerando a hipótese de os autores/interlocutores privilegiarem essas propriedades, constroem-se categorias distintas, ainda que A possa estar incluída em B, em determinada situação, ou ambas apresentem áreas de intersecções.

Talvez essa noção de categoria aponte para uma postura reducionista do processo de categorização, mas antes que questionar sobre esse aparente problema, opta-se aqui por reconhecer que essa noção expressa o princípio elementar de agrupamento e organização de objetos discursivamente, o qual é indissociável do ato de categorizar. A partir desse princípio, pode refletir-se sobre o conceito de categoria (e de categorização), de modo a considerar, como integrantes desse conceito, aspectos e procedimentos discursivos, cognitivos, sociais, históricos, lingüísticos, interacionais.

Um conceito pertinente é o defendido por Mondada (1997) e Mondada e Dubois $(2003)^{8}$. Sua postura, que é de ordem discursiva, nega a rigidez das categorias (de coisas, eventos, indivíduos). Tal rigidez implicaria inserir e manter no texto as categorias pré-estabelecidas (estereotípicas, externas e prévias ao texto em construção). Implicaria estabelecer no texto representação das categorias, conforme elas são concebidas no mundo. Discursivamente, o agrupamento de objetos no texto não se vincula e não corresponde necessariamente ao agrupamento de objetos no mundo. "A atividade categorial não se reduz à atribuição de labels [rótulos] estereotipados a indivíduos ou a objetos, mas diz respeito aos métodos utilizados pelos sujeitos para categorizar, descrever, justificar, compreender os fenômenos da vida cotidiana" (Mondada 1997: 300) ${ }^{9}$. Em linhas gerais, as

\footnotetext{
7 A denominação classe empregada por Lyons é tomada aqui como equivalente a categoria, denominação preferida neste estudo.

8 O texto de Mondada e Dubois foi originalmente publicado em 1995.

9 A tradução do texto de Mondada (1997) é realizada para o presente estudo em particular.
} 
categorias estereotípicas, histórica e socialmente constituídas adaptam-se à produção textual; no âmbito do discurso, ocorre uma identificação sociocultural das categorias pré-estabelecidas.

A rigidez das categorias implicaria, também, necessariamente manter a categoria uma vez introduzida no texto. Mondada e Dubois (2003) defendem que, na construção textual, as categorias são instáveis, dinâmicas, mas que ganham estabilidade discursivamente, por meio da negociação dos interlocutores, submetidas ao contexto sócio-histórico e situacional permeador da produção de dado texto. As categorias - tal como os objetos, que são referidos e categorizados - surgem na intersubjetividade e na visão pública, social e coletiva sobre o mundo, configurando-se como tais no desenrolar do texto, no seio da interação verbal. Em suma, qualquer categoria, uma vez introduzida no texto, pode ser redefinida, reconstruída, reorganizada: processo que, de certo modo, configura-se mediante o uso de diferentes SNs.

As categorias são lingüística e textualmente organizadas, dependentes do contexto e dos interesses dos interlocutores. Mas não são apenas e simplesmente organizadas. Elas também contribuem para a organização da produção e veiculação textual. As categorias presentes no texto, de acordo com Mondada (1997: 298), "tornam o conhecimento inteligível; elas são também procedimentos genéricos de controle social; elas organizam e limitam a maneira pela qual constrói-se um novo conhecimento". Entendese aqui que elas tornam o conhecimento inteligível porque certa propriedade do referente é destacada, apontando, assim, para a interpretação textual adequada acerca desse referente, e, por conseguinte, do conjunto de referentes que compõem o texto. São procedimentos genéricos de controle social porque comportam-se como espécie de feed back ao mundo - e possibilitam um feed back dos interlocutores ao mundo -, contribuindo para a organização e valoração dos objetos no mundo da realidade, da experiência. Elas organizam e limitam a construção de novos conhecimentos porque a identificação da propriedade eleita é indispensável na/para a construção textual do conhecimento acerca dos objetos referidos, e um novo conhecimento implica atentar para novos objetos ou para novas propriedades de objetos conhecidos. Ainda a respeito desse feed back, o autor também "constrói o mundo no curso do cumprimento de suas atividades sociais e o torna estável graças às categorias - notadamente às categorias manifestadas no discurso" (Mondada e Dubois 2003: 20). Isto é, os usuários da língua dão, 
via discurso, estabilidade e organização ao mundo da realidade, extratextual: estabilidade e organização que continuam passíveis de novas modificações via discurso ${ }^{10}$.

A possibilidade de poder referir-se a um objeto a partir de qualquer uma de suas propriedades - fenômeno que diz respeito à categorização condiz com a avaliação ou ponto de vista que o autor emite sobre esse objeto. Em ambos os casos - categorização e avaliação/ponto de vista -, trata-se de escolhas feitas pelo sujeito em dada interação verbal, ainda que seu ponto de vista/avaliação corresponda ao de certo grupo social, instituição, por exemplo. Em outras palavras, em princípio, ao referir, ao ativar e reativar determinado referente, o autor pode inserir na progressão referencial um ponto de vista único, particular, subjetivo, situado contextualmente. Esse fenômeno acha-se no excerto abaixo. Focaliza-se especialmente $\mathrm{CNH}$ e o incidente, foco desse excerto.

\footnotetext{
Excerto 3

O ex-padre irlandês Cornelius Neil Horan[1], de 57 anos, foi condenado ontem pela Justiça grega a um ano de prisão condicional por ter tentado agredir[2] Vanderlei Cordeiro de Lima, quando o brasileiro liderava a prova da maratona dos Jogos Olímpicos. Mas, de acordo com a sentença, ele foi solto após pagar fiança de cerca de US\$3,6 mil. [...]

A intervenção irresponsável de Horan [3] foi considerada " um dos maiores escândalos" da história das Olimpíadas[4] pela imprensa irlandesa. "O bomem que roubou o ouro"'[5] foi o título do jornal Irish Independent, enquanto o Irish Times classifica o fato[6] de "incidente grotesco"[7]. Por sua parte, o Irish Examiner classifica a interferência do ex-padre[8] de "terrorismo"[9], considerando que "cobriu de vergonha" [10] a delegação irlandesa, que festejava sua medalha de ouro conquistada na prova de saltos individuais do hipismo na sexta-feira. (Irlandês paga fiança e já está solto. Texto informativo. EM, CO, 31/8/04, p.3) ${ }^{11}$
}

\footnotetext{
10 Um conceito que certamente contribui no entendimento da relação palavra-mundo, do feed-back do texto ao mundo é o conceito de refração desenvolvido pelo círculo de Bakhtin. Não obstante a pertinência desse conceito, ele não integra o suporte teórico do presente estudo.

11 Os autores dos textos do corpus, freqüentemente, citam fala de outro sujeito (empresa jornalística, por exemplo), a qual configura-se como discurso citado, como mostram as expressões entre aspas no excerto acima e como aponta o próprio autor do texto em questão. Para a análise a se desenvolver neste estudo, o fato de o autor usar desse expediente na construção textual é levado em conta apenas no sentido de observar o ponto de vista e valores atribuídos ao referente originários da fala do outro. A despeito do procedimento metodológico assumido aqui, examinar a correlação entre a referenciação ou categorização e o discurso citado pode oferecer resultados interessantes no que tange à contribuição que o autor do texto encontra em textos de "falantes/autores anteriores".
} 
- O ex-padre irlandês Cornelius Neil Horan [1] refere-se a CNH, a partir de duas propriedades: uma concernente a sua nacionalidade, outra concernente a sua ex-atividade social;

- A intervenção irresponsável de Horan[3] refere-se ao incidente, também a partir de duas propriedades: uma concernente a seu valor ético-moral, outra a seu autor. Nota-se que o sintagma verbal ter tentado agredir[2] contribui para a carga semântico-referencial de [3], no sentido de o aspecto irresponsável de [3] ser entendido como agressão. Nota-se também que o modificador Horan retoma [1];

- "um dos maiores escândalos" da história das Olimpíadas [4] correfere a [3], a partir de duas propriedades: uma concernente a seu valor ético-moral e outra a seu ambiente de ocorrência;

- "O bomem que roubou o ouro"[5] correfere a [1], a partir de propriedade concernente à conseqüência de seu ato durante a maratona;

- ofato[6] correfere a [3];

- "incidente grotesco" [7] correfere a [3], a partir de propriedade concernente a seu valor ético-moral;

- a interferência do ex-padre[8] correfere a [3], a partir de propriedade concernente a seu valor ético-moral. As expressões "terrorismo"[9] e "cobriu de vergonha" [10] contribuem substancialmente para a carga semântico-referencial de [8].

Evidenciam-se os pontos de vista e valores subjetivos, mas também públicos, atribuídos ao incidente e a $\mathrm{CNH}$, concentrando-se SNs veiculados por diferentes jornais.

Deve-se ter em conta que, no texto em que sintagmas nominais desse tipo se encontram - como também nas seqüências hipotéticas construídas e inseridas neste trabalho -, a propriedade eleita ao referir cada objeto pode achar-se implicitada (o que parece, em geral, ocorrer) e, por conseguinte, ser difícil a identificação da(s) categoria(s) que cobre(m) tal objeto. A dificuldade, porém, por certo, permeia apenas a atividade do analista que se propõe a observar a categorização, dado que ele é, em geral, um sujeito externo à interação verbal em foco. Para os interlocutores, a implicitude de propriedades não acarreta qualquer dificuldade, visto que a im- 
plicitude é da natureza da interação e da produção textual. Os interlocutores lidam naturalmente com dados relevantes que se acham implicitados, interagem sem a preocupação de identificar categorias ao longo do texto. Com certeza, para eles, no que tange à categorização, identificar as propriedades eleitas é o suficiente e necessário, tendo em conta que elas contribuem para o limite semântico e temático do texto. Em síntese, a (re)categorização parece ser recurso - de construção temática, de conhecimento, de compreensão textual - geralmente não percebido pelos interlocutores.

\subsection{Construção de categorias: maneiras e regras}

O processo de categorização, ou, construção de categorias, é heterogêneo e pode ser observado de forma diferenciada. Parece que ele ocorre essencialmente de quatro "maneiras" na progressão referencial, expostas a seguir.

(a) Escolha de uma ou mais propriedade do objeto, ao ser introduzido no texto. Isto é, a presença desse objeto (coisas, indivíduos, eventos) no discurso implica que, pelo menos, uma de suas propriedades está sendo eleita.

(b) Escolha de pelo menos uma nova propriedade do objeto já introduzido. Há reativação/retomada do objeto e a propriedade eleita difere da eleita em sua introdução. Nesse caso, o objeto é designado sob nova categoria.

(c) Inclusão de novo objeto em uma categoria já inserida no texto. $\mathrm{A}(\mathrm{s})$ propriedade(s) eleita(s) desse novo objeto corresponde(m) à(s) propriedade(s) eleita(s) na inserção da categoria.

(d) Vários objetos são agrupados a partir de uma propriedade que possuam em comum.

Deve-se ter em conta que as propriedades do objeto que orientam sua categorização podem ser da natureza física do próprio objeto, de natureza social devido ao tratamento dado ao objeto pela comunidade de fala, de natureza subjetiva e cognitiva (inclusive propriedades fantásticas atribuídas aos objetos). As propriedades podem ser de natureza diversa, devido à 
faculdade que têm os interlocutores de "lapidarem", a seu modo, os objetos na interação sócio-verbal. Podendo, assim, a propriedade que serve de orientação ser tida como "inédita" 12 .

Essas "maneiras" podem ser exemplificadas com os SNs componentes da possível e hipotética SEQÜÊNCIA A: o brasileiro que merecia o ouro[1] maratonista do interior do Paraná[2] - outro atleta paranaense[3], em que:

- SN\{1] refere-se a VCL, a partir de propriedades concernentes a sua nacionalidade e a seu feito na prova de maratona. Em [1], aplica-se "maneira" (a);

- SN[2] correfere a [1], a partir das propriedades concernentes a sua especialidade esportiva e a sua origem. Aplica-se "maneira" (b);

- SN[3] refere-se a determinado atleta que não VCL, a partir de propriedade concernente a sua origem, a mesma de VCL. Aplica-se "maneira" (c), em relação à categoria instalada com uso de $\mathrm{SN}[2]$, ou, a categoria instalada com SN[2] acolhe o referente de $\mathrm{SN}[3]$.

Quanto à "maneira" (d), ela pode ser pensada sobre a seqüência acima. Mas ela se torna mais clara se se considerar apenas os SNs [2] e [3]. Essa "maneira" também poderá ser observada na seqüência $B$, a ser inserida ainda nesta seção.

As quatro "maneiras" de categorização postuladas aqui dizem respeito a procedimento, a recurso de seleção e organização de objetos no texto e, por conseguinte, também de organização temática e tópica. Consonante com essas "maneiras" são a regra de economia e a de consistência apresentadas por Mondada (1997).

Mondada chama a atenção para uma forma de ver as categorias pelo comportamento discursivo dos interlocutores, isto é, a autora sugere que se observe "como" os interlocutores recorrem a determinada categoria e

\footnotetext{
12 Poder-se-ia indagar que relação pode haver entre as propriedades de um objeto - nos termos do conceito de categorização exposto aqui - e o conjunto de condições sobre o qual argumenta Milner (2003) ao tratar do significado. Poder-se-ia indagar também se tais condições correspondem à série de propriedades - estereotípicas, naturais, físico-químicas, sócio-culturais, históricas, da subjetividade do enunciador - que um objeto pode ter. Essas questões fogem aos propósitos do presente estudo. Mas, em princípio, há certa correspondência entre propriedades e as condições tratadas por Milner (2003).
} 
não a outras - também "boas" - ao tratarem os objetos/referentes no texto. Em linhas gerais, a postura, neste texto, é a de que o autor - no caso, do texto jornalístico - elege uma das propriedades possíveis, exclusivamente a propriedade que lhe faculta referir o objeto de maneira conveniente e pertinente em dada interação verbal (resultando, assim, em categorização). É muito provável que o autor tenha consciência da escolha que faz quanto à(s) propriedade(s). Ele não se dá conta, porém, ao menos de forma explícita, é da categorização que realiza, como já comentado anteriormente.

Para observar o comportamento dos interlocutores, Mondada (1997: 298) tem em conta que "as categorias se estruturam num dispositivo [...] que compreende coleções de categorias de pertencimento e regras de aplicação dessas categorias"13.

Há interesse aqui por essas regras. Elas se mostram como recurso organizador - que orienta a escolha de propriedades dos objetos referidos e a construção de categorias. As regras, de certo modo, estruturam as categorias. Nas palavras de Mondada (p. 299), a "regra de economia demonstra o fato de que, apesar de um membro poder ser categorizado por várias categorias ao mesmo tempo, uma única é suficiente” ao discurso, ou, para que o referente integre a produção textual. E, a "regra de consistência diz que, se um primeiro membro foi categorizado por um dispositivo, então outros membros da população podem ser categorizados pelo mesmo dispositivo". Observe-se que, com a regra de economia, categorizar um membro/objeto (coisa, indivíduo, evento) é orientar-se pela propriedade eleita no e pelo discurso, pelo ponto de vista do falante, pelo contexto situacional e sóciohistórico, pela relevância sociocultural de tal categoria, pela adequação da

\footnotetext{
13 A coleção de categorias é um fenômeno não explorado no presente estudo. Ainda assim, pode observar-se que a constituição de uma coleção ocorre devido à possibilidade que qualquer membro tem de ser categorizado por diferentes categorias. Com isso, cria-se, conseqüentemente, entre elas um vínculo que lhes dá status de coleção de categorias, a qual é entendida como flexível e dinâmica. Esse processo se explica por uma diversidade de situações, por exemplo, quando determinado objeto perde uma de suas propriedades (atributos, atividades, aspectos, condições), a coleção tende-se também a perder a categoria correspondente a tal propriedade; ou, quando determinado objeto ganha nova propriedade, a coleção também ganha nova categoria, a que é correspondente a tal propriedade. Ou seja, as categorias que compõem uma coleção em torno de certo objeto encontram nesse objeto uma propriedade correspondente. Mesmo que uma coleção de categorias vinculadas "abarque" grande número de categorias, parece que essa coleção é discursivamente constituída e (re)organizada, devido, por exemplo, ao fato de as propriedades comuns ao objeto referido proporcionarem certo imbricamento entre as categorias.
} 
categoria à interação verbal e ao texto. Por outro lado, com o que propõe a regra de consistência, um novo membro não é categorizado a partir propriamente de suas propriedades em si, mas, de certo modo, a partir da propriedade privilegiada pela categoria que o acolhe. Com a regra de consistência, a progressão referencial se caracteriza pela manutenção da categoria inicialmente instalada, pela manutenção e organização do tema em foco.

Uma percepção que se tem dessas regras é a seguinte: a regra de economia motiva e possibilita a heterogeneidade semântico-referencial, porque permite inserir no texto objeto novo, elegendo propriedade também nova ao texto; e a regra de consistência condiciona a homogeneidade, porque diz respeito a olhar um novo objeto a partir da propriedade eleita do objeto inserido anteriormente ${ }^{14}$.

Essas regras dizem respeito especialmente às escolhas feitas pelos interlocutores entre as várias possibilidades ao referir um objeto, e ao procedimento deles ao "manipularem" qualquer objeto na interação sócio-verbal.

Exemplo de progressão referencial em que diferentes objetos achamse sob a mesma categoria é a SEQÜÊNCIA B: hipismo[1] - futebol[2] - vôlei de praia[3]. Nessa seqüência de SNs, aplica-se a regra de economia, pois cada evento é categorizado, em princípio, a partir de apenas uma propriedade a qual é comum a todos e concerne à classificação/premiação dos atletas brasileiros nos Jogos Olímpicos de Atenas 2004 - ; e, em [2] e [3] aplicase a regra de consistência, uma vez que [2] e [3] são categorizados sob a mesma categoria de [1]. Uma possível nomeação dessa categoria seria: modalidades esportivas em que o Brasil ganhou medalha de prata nos Jogos Olímpicos de Atenas 2004.

Em relação às quatro "maneiras" postuladas anteriormente, observese o seguinte na seqüência $B$ :

- SN[1], ocorre "maneira" (a): introdução do referente e escolha de uma de suas propriedades;

14 A partir da hipótese de que a progressão tópica/temática decorra da escolha de propriedades realizada pelos interlocutores ao designarem objetos, talvez investir na correlação entre o dispositivo mencionado por Mondada e o conceito de tema/tópico discursivo seja interessante procedimento para compreender a construção temática/tópica em diferentes gêneros do discurso. Essa questão, porém, não é explorada no presente estudo. 
- SN[2], ocorre "maneira" (a) e (c): inclusão de [2] na categoria de [1], a partir da propriedade que possuem em comum;

- SN[3], ocorre "maneira" (a) e (c): inclusão de [3] na categoria de [1] e [2];

- tomando a seqüência completa, nota-se que ocorre a "maneira" (d): diferentes objetos são agrupados a partir de propriedade comum.

No âmbito do discurso, embora a designação ocorra, minimamente, a partir de uma propriedade do referente - e isso basta para a progressão referencial e compreensão do texto -, os interlocutores podem projetar mais de uma categoria a cada designação; por exemplo, podem caracterizar determinado estádio como "bonito e funcional"; ou, um esporte como "olímpico, de equipe e de afeição dos brasileiros em geral". Embora a "dupla ou múltipla categorização" seja possível, ela não nega a regra de economia apresentada por Mondada. Esse tipo de categorização ocorre, por exemplo, no excerto 3, inserido na seção anterior, particularmente com os SNs [1], [3] e [4], mas também com os SNs [1] e [2] da seqüência A. Essa "dupla ou múltipla categorização" foi apontada, de certo modo, pela "maneira” (a) no início desta seção.

O excerto seguinte também oferece casos em que o $\mathrm{SN}$ ativa mais de uma propriedade do referente.

\section{Excerto 4}

Ele sonhou, na noite que antecedia sua participação nos Jogos Olímpicos, que concluiria sua prova no pódio. Vanderlei Cordeiro de Lima[1] só não imaginava que concretizaria seu sonho de uma forma tão acidentada e surpreendente. No berço da mais tradicional prova do atletismo, o fundista de 35 anos[2] tornou-se o primeiro brasileiro a conquistar uma medalha na maratona[3], ficando com o bronze ao completar os $42.195 \mathrm{~m}$ entre a cidade de Maratona e o Estádio Panathinaikos em 2h12min11. Poderia, no entanto, ter sido o ouro. (Vanderlei é exemplo de elegância e superação. Texto informativo, EM, CO, 30/8/04, p.31)

- Vanderlei Cordeiro de Lima[1] refere-se a VCL. Por seu nome próprio, parece que sua categorização elege todas as propriedades de VCL conhecidas textual e socialmente. O nome próprio talvez seja um tipo de SN diferente dos demais, no que tange à categorização. Em face dessa observação, o procedimento, no desenrolar deste estudo, é o de não tecer comentários sobre o SN composto exclusi- 
vamente de nome próprio (seja de VCL ou de $\mathrm{CNH}$ ), embora ele seja destacado nos excertos, reconhecendo, assim, sua importância na referenciação e na categorização;

- ofundista de 35 anos[2] correfere a [1], a partir de duas propriedades: uma especialidade do atletismo e a idade de VCL. Não ocorre regra de economia nem de consistência;

- o primeiro brasileiro a conquistar uma medalba na maratona[3] correfere a [1], também a partir de mais de uma propriedade: a nacionalidade de VCL e o ineditismo da medalha para o Brasil. Não ocorre regra de economia nem de consistência.

Apoiar-se apenas na regra de economia significa ter em conta que o referente é categorizado a partir apenas de uma única propriedade - preferencialmente a mais evidente - a cada designação. Todavia, tomando a composição formal dos SNs como ponto de partida para análise, não se pode ignorar a relevância das propriedades do referente explicitamente ativadas no texto. Desse modo, no presente estudo, em ocorrência como as apontadas nos excertos 3 ou 4, procura-se considerar a "dupla ou múltipla categorização" do referente. Esse procedimento metodológico funda-se, portanto, em razões teóricas e empíricas.

Mas, ainda assim, poder-se-ia postular que, na produção textual, ocorre espécie de disputa por uma ou outra propriedade e a progressão referencial acontece no sentido de privilegiar uma categoria em detrimento de outras possíveis do objeto. Não a rigor, porém.

Cabe pensar as alterações a que o referente está sujeito ao longo do texto, como as observadas no excerto 4. Trata-se da recategorização. Esse é o foco da seção seguinte.

\subsection{Recategorização: inserindo categorias novas no texto}

A "manipulação" dos interlocutores sobre os objetos de discurso pode ocorrer ao longo do texto, reativando-os sob o mesmo ponto de vista ou reavaliando-os. O caso em que determinado objeto é reavaliado, submetido a novo ponto de vista, implica que ele é designado a partir de nova propriedade, ocorrendo, assim, recategorização. Grosso modo, tipicamente 
a recategorização ocorre quando determinado objeto, ao ser reativado, é designado a partir de propriedade diferente da eleita na designação anterior.

Atentam Mondada e Dubois (2003: 25), “a 'mesma' cena [ou indivíduo, ou coisa] pode [...] ser tematizada diferentemente e pode evoluir - no tempo discursivo e narrativo - focalizando diferentes partes ou aspectos." E focalizar diferentes propriedades (aspectos, atributos, condições, atividades, "partes") do referente a cada designação é recategorizá-lo. Para focalizar uma ou outra propriedade do referente - o que pode implicar novo ponto de vista e avaliação -, o autor tem como recurso lingüístico um novo $\mathrm{SN}$, sobretudo mediante uso de novos modificadores do nome-núcleo. Esse processo pode ser observado, por exemplo, nos SNs [2] e [3] do excerto 4 , inserido anteriormente.

Outro caso desse processo ocorre na possível SEQÜÊNCIA C: a principal prova da vida de Vanderlei[1] - a sua maratona[2] - uma prova que exige muita concentração[3] - um evento com falha da organização [4], em que os quatro SNs correferem-se. Quanto à (re)categorização, observe-se:

- SN[1] refere-se à maratona dos Jogos Olímpicos de Atenas 2004, a partir de propriedade concernente à importância dessa prova para VCL. Aplica-se a "maneira" (a) e a regra de economia;

- SN[2] correfere a [1], a partir da mesma propriedade - o determinante sua é crucial na ativação dessa propriedade -; não há recategorização. Aplica-se a "maneira” (a), a regra de economia e a de consistência;

- SN[3] correfere a [1], a partir de sua propriedade (valorativa) concernente ao envolvimento dos participantes com a prova; há recategorização. Aplica-se a "maneira" (a) e (b), e a regra de economia. Os SNs [1] e [3] possuem o mesmo nome-núcleo, cabendo aos modificadores as distinções entre ambos os SNs.

- SN[4] correfere a [1], a partir de propriedade concernente a incidente ocorrido VCL; há recategorização. Aplica-se a "maneira" (a) e (b), e a regra de economia.

A reflexão tecida sobre os $\mathrm{SNs}$ destacados do excerto 4 e sobre a seqüência $C$ focaliza especialmente a progressão referencial caracterizada por correferência, a construção de um único objeto: à medida que é retomado correferencialmente, ele pode ser também recategorizado, ser designado a 
partir de propriedade distinta da anterior, tematizado diferentemente, redefinido, delineado no desenrolar do discurso.

A recategorização, entretanto, ocorre também na progressão não-correferencial, que envolva mais de um referente, pois o autor pode introduzir referente novo elegendo propriedade "estranha" à progressão referencial já desenvolvida e que, portanto, condiciona a presença de nova categoria. Para que esse processo ocorra, é necessário que exista entre os SNs alguma relação semântico-referencial no âmbito do texto. Recategorização dessa ordem se dá, por exemplo, quando a relação entre dois (ou mais) referentes é do tipo todo-parte, classe-membro, hipo-/hiperonímia, associação, metonímia. Nesse caso - de recategorização não-correferencial -, embora ocorra reativação do referente-antecedente, há introdução de referente novo. Por exemplo, a SEQÜÊENCIA D: as Olimpíadas de 2004[1] - a disputa da última medalha[2] - uma medalha de bronze[3], em que:

- SN $[1]$ refere-se ao evento olímpico ocorrido em Atenas em 2004, a partir de propriedade concernente ao local e ano de realização. Aplicase a "maneira" (a), mas nenhuma das regras;

- SN[2], à maratona do evento referido por [1], a partir de propriedade concernente ao fato de a maratona ser a última prova a ser disputada nesse tipo de evento; há recategorização. Aplica-se a "maneira" (a) e a regra de economia. Entre [1] e [2] há relação hiperonímica;

- SN[3], à medalha recebida pelo maratonista VCL, a partir de propriedade concernente a sua posição de chegada; há recategorização. Aplica-se a "maneira" (a) e a regra de economia. Entre [1] e [3] e entre [2] e [3] há associação.

Outro exemplo de progressão não-correferencial ocorre abaixo.

\section{Excerto 5}

Vanderlei Cordeiro de Lima[1] procurou Martinho Nobre dos Santos, chefe de equipe do atletismo [2], logo depois da estranha maratona olímpica [3], domingo. Queria saber quando todo mundo[4] voltaria ao Brasil. Há cerca de dois meses, o paranaense está longe de casa e doido de saudades de Cruzeiro d'Oeste (PR), sua cidade natal. Claro que tinha ficado chateado com o incidente que o atrapalbou na prova[5], mas, ainda assim, curtia o bronze. Agora, só pretende descansar. (I.Drummond e L.Meireles. Vanderlei longe da briga. Texto informativo, EM, CO, 31/8/04, p.3) 
Focaliza-se aqui em especial duas relações: entre [2] e [4], e entre [3] e [5], entendendo que a relação entre os dois SNs é do tipo todo-parte, hipo-/hiperonímia, associação.

- equipe do atletismo[2] refere-se ao grupo de atletas a que pertence VCL, a partir de propriedade concernente à sua modalidade esportiva. Aplica-se "maneira" (a) e regra de economia;

- todo mundo[4], ao grupo de brasileiros do atletismo presentes em Atenas, a partir de propriedade concernente ao fato de estar em Atenas. Há recategorização em relação a [2]. Aplica-se "maneira" (a) e regra de economia. Observe-se que VCL inclui-se tanto em [2] quanto em [4], embora [2] e [4] sejam grupos distintos;

- da estranha maratona olímpica[3] refere-se à maratona dos Jogos Olímpicos de Atenas, a partir de propriedade concernente ao episódio, a um componente dessa maratona. Aplica-se "maneira" (a) e regra de economia;

- o incidente que o atrapalbou na prova[5] refere-se ao episódio evidenciado na maratona referida por [3] e que a tornou estranha, a partir de propriedade concernente a seu efeito sobre VCL (particularmente sua posição de chegada). Há recategorização em relação a [3]. Aplica-se "maneira" (a) e regra de economia.

Em linhas gerais, pode-se observar que, com o emprego de diferentes SNs, e cada qual ativando seu significado particular, evidencia-se uma heterogeneidade semântica ao longo do texto. O emprego de SNs diversos, na perspectiva dos autores, parece ser motivado pela "necessidade" de designação de referentes novos e pela possibilidade de escolha de propriedades diferenciadas acerca de cada referente ${ }^{15}$. Consonante com essa breve observação são as palavras de Koch e Marcuschi (1998: 174): "a noção de recategorização pode ser tomada como uma categoria fundamental para explicar os processos de heterogeneidade semântica no processamento textual." Ou seja, identificar a propriedade e a categoria que envolve os SNs e os objetos referidos significa lidar com significados e sentidos constituintes

15 Para pensar essa heterogeneidade semântica, é possível apoiar-se, por exemplo, no trabalho de Milner (2003), para quem, em suma, cada forma nominal possui significado particular. 
da interação verbal, possibilitando, assim, entender como os significados e sentidos são tecidos no texto.

Considerar o referente como objeto que pode ser categorizado a partir de mais de uma propriedade possibilita examinar a heterogeneidade semântica na construção textual, pois essa heterogeneidade somente pode ser explicada se se reconhecer "todas" as propriedades dos referentes eleitas a cada designação, ao referir, ao (re)categorizar.

A seção seguinte é dedicada à exposição do corpus de que se serve o presente estudo e à observação empírica dos dados.

\section{Escrita jornalística: breve observação empírica}

Os textos que compõem o corpus deste estudo foram publicados no jornal Estado de Minas e nas revistas Veja e Istoé, na semana subseqüente ao encerramento dos Jogos Olímpicos realizados em Atenas, na Grécia, em 2004. Os textos têm como tema a prova de maratona desses Jogos, em especial o episódio ocorrido com o maratonista brasileiro VCL, em que o irlandês $\mathrm{CNH}$ interceptou-o por volta do $\mathrm{km} \mathrm{35}$, interferindo substancialmente no desempenho do atleta e no resultado da prova. Do tema, portanto, elege-se os objetos de discurso preferencialmente a serem focalizados: o episódio, VCL e CNH, mesmo sabendo da relevância de outros objetos na construção textual.

Os textos são divididos aqui em dois grupos, considerando que se caracterizam em informativos e opinativos. Os critérios para agrupá-los são o fato de apresentarem características típicas da informação ou da opinião, além do espaço em que são publicados nos jornais e revistas: em geral, os textos informativos são publicados em cadernos ou seções de esportes, enquanto os opinativos em seções de opinião. Ainda assim, talvez agrupá-los em dois blocos distintos seja um procedimento grosseiro, tendo em conta que não só os opinativos são, por exemplo, assinados pelo articulista, mas também alguns informativos são assinados pelo repórter. E mais, em geral, um mesmo texto constitui-se de elementos informativos e de elementos opinativos; diante disso, procuramos classificá-los conforme a prevalência desses elementos. 
A hipótese aqui é a de que a prática de (re)categorizar está condicionada a aspectos informativos e opinativos constituintes do texto. Mais especificamente, a hipótese é a de que o uso de SNs que expressam opinião e valores do autor é mais freqüente no texto opinativo do que no informativo, pois o opinativo é tipicamente espaço de avaliação e crítica, de expressão de ponto de vista e de valores. Assume-se o pressuposto de que os autores, ao expressarem suas idéias e opiniões a respeito de objetos e fatos sociais, de certo modo, expressam também aquelas compartilhadas por seus leitores, pelos demais indivíduos de seu grupo social ou de sua comunidade lingüística, especialmente as opiniões e valores pertinentes ao momento histórico de dada produção textual e do tema abordado pelo autor.

As quatro "maneiras" de categorização e as duas regras apresentadas na seção 3.1 serão levadas em conta nesta análise. Considera-se facultativa a aplicação da regra de economia, conforme reflexão tecida sobre os excertos 3 e 4 . O procedimento assumido aqui parece coerente com o processo de (re)categorização em geral, com a heterogeneidade semântica do texto. Quanto à regra de consistência, menção lhe será feita quando de sua ocorrência. Vale enfatizar, essa regra é aplicada em referentes distintos sob mesma categoria.

Inserem-se excertos de textos do corpus com o intuito de identificar e compreender particularidades do processo de (re)categorização no texto jornalístico de caráter informativo ou opinativo, especialmente aquelas concernentes ao procedimento do autor ao referir e (re)categorizar os objetos referidos, e aquelas particularidades relativas aos valores que o autor lhes atribui. O procedimento de análise, em síntese, consiste em compreender a aplicação e ocorrência das quatro "maneiras" e das duas regras de construção de categorias.

\section{GRUPO DE TEXTOS INFORMATIVOS}

\section{Excerto 6}

[...] Assim é possível descrever o que se passou com Vanderlei Cordeiro de Lima ${ }^{16}$ [1] ao ter seu progresso na maratona atrapalbado pelo irlandês Neil Horan[2]. Para o

\footnotetext{
16 Conforme já exposto ao comentar sobre o excerto 4, SNs compostos exclusivamente por nome próprio serão destacados nos excertos, dada sua relevância no processo referencial, mas não serão comentados individualmente como dos demais SNs.
} 
professor de fisiologia da Escola de Educação Física da UFMG, Emerson Silami Garcia, acostumado a trabalhar com atletas de alto nível[3], o fato de o paranaense [4] ter retomado o percurso ainda em condição de completar os $42.195 \mathrm{~m}$ em terceiro lugar é um exemplo de superação atlética.

"Os efeitos sobre o organismo do atleta[5] em uma circunstância como essa são terríveis. [...] certamente, completou a prova com o emocional abalado. Como iria imaginar que, no meio de uma maratona, surgiria um cidadão[6] justamente para atacá-lo[7]? Poderia ser um terrorista[8] com uma bomba”, alega. (R.Geni, Mais do que um susto. EM, CO, 30/8/04, p.31)

- seu progresso na maratona atrapalhado pelo irlandês Neil Horan[2] refere-se ao desenvolvimento de VCL na maratona olímpica de 2004, a partir de várias propriedades: uma concernente à competição (maratona), outra ao incidente e outra à nacionalidade de $\mathrm{CNH}$. Aplica-se "maneira" (a), mas nenhuma das regras;

- atletas de alto nível[3] refere-se a determinado grupo de atletas a que pertence VCL, a partir de propriedade concernente a sua preparação/treinamento. Aplica-se "maneira" (a) e regra de economia. Há recategorização não-correferencial em relação a [1]. Entre [1] e [3] há relação de hiponímia.

- oparanaense $[4]$ correfere a $[1]$, a partir de propriedade concernente a sua origem. Aplica-se "maneira" (a) e (b), e regra de economia. Há recategorização correferencial em relação a $[1]$ e recategorização nãocorreferencial em relação a [3]. Entre [3] e [4] há relação de hiperonímia;

- "Os efeitos sobre o organismo do atleta[5] refere-se à ação sobre o organismo de VCL em conseqüência do incidente, a partir de propriedade concernente à reação físico-química após o episódio. Aplica-se "maneira" (a) e regra de economia. Há recategorização não-correferencial em relação a [2], por exemplo;

- um cidadão[6] refere-se a VCL, a partir de propriedade genérica. Aplica-se "maneira" (a) e regra de economia. Entre [2] e [6] há relação associativa, no sentido de [6] ser o agente atrapalhador ativado em [2];

- um terrorista[8] correfere a [6], a partir de propriedade hipotética concernente a sua atitude. Aplica-se "maneira" (a) e (b), e regra de economia. Há recategorização correferencial em relação a [6]. 
Nesse texto, o autor não insere explicitamente seu ponto de vista sobre os referentes, o que condiz com o texto informativo. Mas, com o uso da fala de Emerson S. Garcia, há expressão de valores sobre o episódio e $\mathrm{CNH}$, sobretudo mediante atacá-lo[7] e um terrorista[8]. Aliás, a forma verbal do tipo [7] é muito empregada em referência à atitude de $\mathrm{CNH}$; nesse caso particularmente, a atitude é entendida como ataque.

\section{Excerto 7}

Os dirigentes do Comitê Olímpico Brasileiro (COB) [...] entrarão com recurso na Corte Arbitral do Esporte (CAS), em Genebra, em que também pleitearão uma indenização. $O$ esforço do brasileiro [1] foi reconhecido pelo COI com o oferecimento da medalha Pierre de Coubertin [2], que premia exemplos de valorização do espírito olímpico[3] e só havia sido oferecida ao velejador alemão Huber Radaschl que, em Seul'88, abandonou uma regata para salvar uma pessoa que se afogava. (Vanderlei é exemplo de elegância e superação. EM, CO, 30/8/04, p.31)

- O esforço do brasileiro[1] refere-se ao comportamento de VCL após o episódio, a partir de propriedade concernente a VCL. Aplica-se "maneira" (a) e regra de economia. Nesse SN, o nome-núcleo esforço, de certo modo, é uma característica do modificador do brasileiro, conectado ao nome-núcleo por preposição que indica "posse";

- o oferecimento da medalha Pierre de Coubertin[2] refere-se à premiação extra obtida por VCL, a partir de duas propriedades: uma concernente ao objeto oferecido (medalha), outra ao criador dos Jogos Olímpicos da Era Moderna. Aplica-se "maneira" (a), mas não se aplica nenhuma das regras. Esse SN estabelece associação com [1], no sentido de o oferecimento[2] ocorrer devido ao esforço[1].

- exemplos de valorização do espírito olímpico[3] refere-se a determinados atletas olímpicos, a partir de propriedade concernente a valores ético-morais, extra-esporte. Aplica-se "maneira" (a) e regra de economia. O modificador de [3], tal como o título do texto - Vanderlei é exemplo de elegância e superação -, faz remissão à atitude éticomoral de VCL. Esse SN estabelece associação com [1], no sentido de VCL ser exemplo de valoração do esporte olímpico, devido a seu esforço na maratona, e, também, por não mostrar reação contra $\mathrm{CNH}$. $\mathrm{SN}[3]$ estabelece associação também com [2], no sentido de a medalha ser oferecida a atletas que, de fato, valorizam o esporte olímpico. 
O título do texto faz remissão ao comportamento ético-moral de VCL, que não se irritou nem proferiu qualquer palavra agressiva diante da intercepção de $\mathrm{CNH}$, durante ou após a prova, mas sim se comportou como gentleman e esforçou-se para superar as dificuldades físicas e emocionais desencadeadas pelo incidente, e, assim, chegar ao Estádio Panathinaikos feliz, com sorriso no rosto.

Com os SNs destacados, o autor do texto - aliás, texto informativo não assinado - não revela explicitamente seu ponto de vista, sua valoração a VCL, em sim, explicita o ponto de vista e valores atribuídos a VCL pelo Comitê Olímpico Internacional (COI).

\section{Excerto 8}

Gesta espera que todos se lembrem de que $\boldsymbol{o}$ brasileiro[1] só saiu da primeira colocação "por causa de um débil mental[2]". "Quando alguém falar da maratona de Atenas, daqui a muitos anos, que se lembre vagamente que um italiano venceu a prova. Mas que se lembre bem que o brasileiro Vanderlei Cordeiro de Lima[3] poderia ter ganho". (I.Drummond e L.Meireles. Vanderlei longe da briga, EM, CO, 31/8/04, p.3)

- o brasileiro[1] refere-se a VCL, a partir de propriedade concernente a sua nacionalidade. Aplica-se "maneira" (a) e regra de economia;

- um débil mental[2] refere-se a $\mathrm{CNH}$, a partir de propriedade concernente a sua condição psíquica. Aplica-se "maneira" (a) e regra de economia. A propriedade atribuída e eleita de $\mathrm{CNH}$ expressa a valoração do enunciador da fala citada;

- o brasileiro Vanderlei Cordeiro de Lima[3] correfere a [1], a partir da mesma propriedade, mantendo a mesma categoria projetada por [1]. Aplica-se "maneira" (a) e regra de economia.

\section{Excerto 9}

Saiba como vive o mais novo ídolo do Brasil[1], um ex-bóia-fria que ganbava $\mathbf{R} \$$ 12 por dia $[2]$.

Acredite, o irlandês maluco[3] foi só o último obstáculo do nosso herói em Atenas[4]. (Manchete de capa. Isto é, 1822, 08/9/04)

- o mais novo ídolo do Brasil[1] refere-se a VCL, a partir de propriedade concernente à repercussão de seu procedimento para com o 
episódio e para com $\mathrm{CNH}$, e de propriedade concernente a sua nacionalidade. A propriedade ativada não concerne diretamente à colocação na maratona ou à medalha recebida. Aplica-se "maneira" (a), mas não regra de economia. SN[1] revela certa avaliação pública sobre VCL;

- um ex-bóia-fria que ganhava $\boldsymbol{R} \$ 12$ por dia[2] correfere a [1], a partir também de duas propriedades: uma concernente a sua "exprofissão", outra ao salário correspondente a essa "profissão". Aplica-se "maneira" (a), mas não regra de economia. Há recategorização correferencial em relação a [1];

- o irlandês maluco[3] refere-se a $\mathrm{CNH}$, a partir de duas propriedades: uma concernente a sua nacionalidade, outra a sua condição psíquica, ainda que metaforicamente. Aplica-se "maneira" (a), mas não regra de economia. Com esse $\mathrm{SN}$, a revista revela seu ponto de vista e avaliação, que também é pública, sobre $\mathrm{CNH}$;

- o último obstáculo do nosso herói em Atenas[4] refere-se ao episódio, a partir de três propriedades: concernentes ao local de ocorrência, a quem (VCL) desafiou tal obstáculo e ao fato de VCL já ter passado por vários obstáculos na vida. Nota-se que VCL é modificador do nome-núcleo obstáculo, o qual não é característica de VCL, como parece ser freqüente noutros casos em que VCL é também modificador. Mesmo VCL sendo modificador, ele ativa a mesma propriedade ativada por [1]. Essa identidade quanto à propriedade, conforme procedimento metodológico assumido, não permite, porém, considerar que VCL - ativado por [1] e por [4] - está sob mesma categoria. Ambos os SNs referem-se a objetos distintos. Em SN [4], aplica-se "maneira" (a), mas não regra de economia. Há recategorização não-correferencial em relação a [1] e a [2]. Entre [1] e [4] há relação de associação.

No tocante ao ponto de vista e valores atribuídos aos referentes, enfatiza-se que os quatro SNs destacados expressam valores públicos, que condizem com os dos leitores em geral, haja vista o fato de o excerto ser oriundo da capa de revista semanal. 


\section{GRUPO DE TEXTOS OPINATIVOS}

\section{Excerto 10}

Milhões de dólares foram gastos para que os Jogos Olímpicos de Atenas transcorressem em clima de paz e um monumental esquema de segurança impedisse a ação de terroristas. O esforço quase foi perfeito, mas acabou traído pela ingenuidade de um conbecido agitador[1], que já havia feito das suas no circuito de Silverstone. Vanderlei Cordeiro de Lima[2] nada tinha a ver com as supostas causas do irlandês Neil Horan [3] e quase viu seu esforço[4] por água abaixo - perdeu a chance de brigar pelo ouro. $O$ episódio[5], que se transformou na imagem do último dia da Olimpíada[6], mostra que toda a preocupação e cuidado em eventos deste porte nunca são excessivos. (R.Geni. Sem título, EM, CO, Seção Análise da notícia, 30/8/04, p.31)

- pela ingenuidade de um conbecido agitador [1] refere-se a uma característica moral de $\mathrm{CNH}$, a partir de mais de uma propriedade: concernentes a sua condição ético-moral e a outras atitudes semelhantes praticadas. Aplica-se "maneira" (a), mas não a regra de economia. Nesse SN, o nome-núcleo ingenuidade é uma característica do modificador de um conhecido agitador, que é $\mathrm{CNH}$. Ou, o elemento preposicional que conecta o modificador ao nome núcleo indica "posse". Tanto o nome-núcleo quanto o modificador expressam o ponto de vista/valores do autor do texto;

- as supostas causas do irlandês Neil Horan[3] refere-se a causas hipotéticas que levaram $\mathrm{CNH}$ a interceptar VCL, a partir de três propriedades: concernentes ao fato de serem supostas/hipotéticas, ao seu detentor - $\mathrm{CNH}$ - e a sua nacionalidade. Há recategorização não-correferencial em relação a [1]. Aplica-se "maneira" (a), mas não a regra de economia;

- seu esforço[4] refere-se ao treinamento e dedicação de VCL como atleta, a partir de propriedade concernente a VCL. Esse SN revela certa avaliação do autor sobre VCL. Aplica-se "maneira" (a) e regra de economia. Há recategorizacao não-correferencial em relação a [2]. Entre [2] e [4] há relação de associação.

- O episódio[5] refere-se ao episódio de forma genérica, sem eleger uma propriedade exclusivamente: parece coerente considerar que não se aplica regra de economia. Aplica-se "maneira" (a);

- na imagem do último dia da Olimpíada[6] correfere a [5], a partir de duas propriedades: concernentes ao "quando" e ao fato de per- 
tencer aos Jogos Olímpicos de Atenas. Há recategorização correferencial em relação a [5]. Aplica-se "maneira" (a) e (b), mas não regra de economia.

Esse texto, embora seja assinado e publicado em seção, em princípio, de opinião, revela poucos valores e pontos de vista do autor. Aqui, ocorre o contrário do que se pressupõe sobre esse tipo de texto.

\section{Excerto 11}

Alguns leitores me acusaram de estar por trás de Cornelius Horan, o fanático religioso que, para anunciar of fim do mundo, interrompeu a marcha do maratonista brasileiro Vanderlei de Lima[1]. Uma goiana disse que usei meus poderes vodus para assegurar a vitória do "carcamano que surrupiou o ouro"[2]. Um paraense disse que me irritei com o bom desempenho de nossos atletas [3] e torci contra Vanderlei de Lima[4], que só não ganhou a maratona por causa daquele "maluco do Primeiro Mundo" [5]. [...] Um paranaense disse que Horan[6], na realidade, sou $\mathrm{eu}$, de saiote, disposto a praticar qualquer indignidade para garantir a ultrapassagem do maratonista americano[7], porque minha meta é "derrubar o sonho dos brasileiros".

Primeiro: Horan [8] está certo. O fim do mundo é mais importante que uma maratona. Arrependa-se. Os pecadores irão arder para sempre no fogo do inferno.

Segundo: se não fosse por Horan[9], Vanderlei de Lima[10] não só não teria ganho a medalha de ouro como teria chegado, pelos meus cálculos, em sétimo lugar. Àquela altura da maratona, ele estava perdendo mais de vinte segundos por quilômetro. $O$ incidente com Horan [11] deu-lhe um gás a mais. $\mathrm{O}$ italiano que ganhou a maratona disse que, se tivesse acontecido com ele, simplesmente teria dado um safanão no intruso[12] e seguido em frente.

Terceiro: os brasileiros são muito mais malucos que Horan [13]. Sentem-se perseguidos pelo resto do mundo. Vêem maquinações dos países ricos [14] em todos os seus fracassos[15]. Acreditam que o episódio com Vanderlei de Lima[16] só ocorreu porque a maratona estava sendo dominada por um brasileiro[17]. Os vencedores das três últimas maratonas olímpicas foram um coreano, um sul-africano e um etíope. (D.Mainardi. O irlandês ajudou. Veja, 08/9/04, p.147)

- Cornelius Horan, ofanático religioso que, para anunciar ofim do mundo, interrompeu a marcha do maratonista brasileiro Vanderlei de Lima [1] refere-se a CNH, a partir de três propriedades: concernentes a sua postura religiosa, à finalidade com que agiu contra VCL, à ação contra VCL. Ocorre avaliação implícita do referente, mas não por parte do autor, e sim, por parte de alguns de seus leitores. Aplica-se "maneira" (a), mas não regra de economia; 
- a vitória do "carcamano que surrupiou o ouro"[2] refere-se à posição de chegada de Stefano Baldini na maratona, a partir de duas propriedades: concernentes ao atleta vencedor da prova e ao fato de aproveitar da situação obtendo a primeira colocação e a medalha de ouro. Revelam-se ponto de vista e avaliação sobre o referente com uso de discurso citado. Aplica-se "maneira" (a), mas não regra de economia;

- o bom desempenho de nossos atletas [3] refere-se ao desempenho dos atletas brasileiros nos Jogos Olímpicos em questão, a partir de duas propriedades: concernentes a seus aspectos positivos e a seus agentes. Aplica-se "maneira" (a), mas não regra de economia;

- Vanderlei de Lima[4] estabelece relação de associação com [3], no sentido de que o VCL é um dos atletas que tiveram bom desempenho nesses Jogos. Há recategorização não-correferencial entre [3] e [4];

- daquele "maluco do Primeiro Mundo" [5] refere-se a CNH, a partir de duas propriedades: concernentes a sua condição psíquica e a sua nacionalidade. Ocorre avaliação sobre $\mathrm{CNH}$, com uso de discurso citado. Aplica-se "maneira" (a), mas não regra de economia. Há recategorização correferencial em relação a [1];

- qualquer indignidade para garantir a ultrapassagem do maratonista americano[7] refere-se a atos negativos hipotéticos do autor do texto, a partir de duas propriedades: concernentes a sua finalidade e ao atleta beneficiado por tais atos. Refere-se indiretamente ao episódio causado por CNH. Aplica-se "maneira" (a), mas não regra de economia;

- O incidente com Horan[11] refere-se ao episódio, a partir de propriedade concernente a seu agente - $\mathrm{CNH}$. Aplica-se "maneira" (a) e regra de economia. Há recategorização correferencial em relação a [7], com que estabelece relação do tipo classe-membro; e recategorização não-correferencial em relação a [1], [5], [6], [8] e [9], com os quais [11] estabelece relação de associação;

- no intruso[12] refere-se a $\mathrm{CNH}$, a partir de propriedade concernente a sua intercepção na maratona. Aplica-se "maneira" (a) e regra de economia. Há recategorização correferencial em relação a [1] e 
a [5], por exemplo; e recategorização não-correferencial em relação a $[11]$, com que estabelece relação de associação;

- maquinações dos países ricos [14] refere-se a atitudes negativas contra os brasileiros, a partir de propriedade concernente a seus praticantes. Aplica-se "maneira" (a) e regra de economia. Há recategorização não-correferencial em relação a [7] e [11]. Entre [11] e [14] há relação do tipo membro-classe;

- todos os seus fracassos [15] refere-se a maus desempenhos dos brasileiros em quaisquer atividades, a partir de propriedade concernente aos brasileiros. Aplica-se "maneira" (a) e regra de economia. Há recategorização não-correferencial em relação a [7], [11] e [14];

- o episódio com Vanderlei de Lima[16] refere-se ao episódio provocado por $\mathrm{CNH}$, a partir de propriedade concernente a VCL. Aplicase "maneira" (a) e regra de economia. Há recategorização correferencial em relação a [11] e não-correferencial em relação a [4], [7], [10] e [14];

- um brasileiro[17] refere-se a VCL, a partir de propriedade concernente a sua nacionalidade. Aplica-se "maneira" (a) e regra de economia. Há recategorização correferencial em relação a [4] e [10], e não-correferencial em relação a [1], [3], [15] e [16].

Entre os SNs destacados acima, vários revelam valores e pontos de vista sobre VCL, CNH e o episódio, mas, em geral, esses SNs são de discurso citado, poucos são da voz do autor. Os valores e pontos de vista que o autor dedica aos três referentes ocorrem na construção temática do texto por inteiro, no entremeio dos SNs. E esse fenômeno parece ocorrer de forma evidente nesse excerto, enquanto, nos demais excertos, ocorre de forma velada.

\section{Excerto 12}

O espirito olímpico[1]...

O espirito de porco[2]... (Son Salvador, Sem título. Charge. EM, CO, 31/8/04, p.3)

- O espírito olímpico[1] refere-se a VCL, a partir de propriedade concernente a seus valores esportivos e ético-morais. Aplica-se "maneira" (a) e regra de economia; 
- O espírito de porco[2] refere-se a $\mathrm{CNH}$, a partir de propriedade concernente a seus valores ético-morais, que são distintos dos apontados sobre SN[1]. Há recategorização não-correferencial. Aplicase "maneira" (a), (c) e (d), e regra de economia.

Por certo, a charge é um tipo de texto estritamente opinativo, em que o autor expressa valores próprios e/ou sociais, pertencentes a um grupo de pessoas ou a toda a sociedade. Os SNs empregados por Son Salvador, de certo modo, sintetizam o que a maioria dos brasileiros expressaram sobre VCL e CNH, em face do episódio e da atitude de VCL. Um aspecto a se observar é que $\mathrm{SN}[1]$ é expressão corrente nesse tipo de Jogos, a qual revela a característica esperada de todos os participantes, enquanto SN[2] é popular - talvez típica da cultura brasileira - e revela má conduta de um indivíduo onde e quando se espera boa conduta de todos.

\section{Considerações finais}

Tanto a reflexão tecida em torno das seqüencias de SNs construídas/ hipotéticas, quanto a tecida a partir de excertos, corroboram a postura de Mondada e Dubois (2003) e de Mondada (1997), segundo a qual as categorias não são dadas a priori, mas constituídas no desenvolvimento do discurso, imersas na prática social de um grupo de sujeitos, dependentes do "olhar" dos interlocutores sobre a realidade física e social, dependentes de uma prática pessoal que reconheça e eleja determinada propriedade do objeto ao designá-lo.

De uma maneira geral, identifica-se instabilidade das expressões e designações lingüísticas, tanto no que tange à referência ao objeto, quanto à sua (re)categorização. Essa instabilidade não deve ser entendida como dificuldade de comunicação ou desconhecimento do autor/interlocutores sobre o mundo, mas sim como característica imanente dos processos de referenciação e de categorização, como interessante estratégia de delinear, referir e categorizar os objetos discursivamente.

A partir da breve análise, não se pode afirmar que a inserção de novo ponto de vista, (re)avaliação do referente em textos jornalísticos seja mais comum ao texto opinativo que ao informativo. Mas, a análise mostrou 
que, no texto informativo, o ponto de vista e valores sobre o referente são ativados freqüentemente pelo uso do discurso do outro, da fala citada; enquanto que, no texto opinativo, mescla-se o uso de SNs do discurso citado com o uso de SNs da fala do próprio autor. Essa particularidade do texto opinativo, com certeza, se justifica pelo fato de esse texto ser espaço próprio para o autor apresentar seu ponto de vista e valores sobre os objetos referidos, dialogar diretamente com outros autores e com seus leitores, como também ser espaço para o leitor encontrar ressonância da própria voz, ou confrontá-la.

Quanto à regra de consistência, a análise mostrou que ela é pouco freqüente. Raramente faz-se referência a dois ou mais objetos sob mesma categoria, ou seja, a "maneira" (c) ou (d) são de baixa ocorrência. Uma possível justificativa para esse fenômeno é o fato de o tipo de corpus - inclusive no tocante ao tema e a seu aspecto jornalístico - de que se serviu possuir características não condizentes com essa regra, a qual condiciona a manutenção da categoria e do tema inicialmente instalados, a qual condiciona a homogeneidade semântico-referencial no texto. Isto é, tanto o texto jornalístico informativo, quanto o opinativo, constituem-se, por exemplo, de objetos e de categorias distintos e variados, de heterogeneidade semântico-referencial motivada pela escolha diversa de propriedades dos objetos referidos e categorizados. Essa heterogeneidade não condiz com a regra de economia, mas também não a inibe. Na verdade, a heterogeneidade semântica é maior quanto menor for a ocorrência dessa regra.

Em síntese, em ambos os tipos de texto, há fatores - em princípio, desconhecidos - que inibem o uso de SNs condizentes com manutenção e estabilidade do referente e de suas propriedades ao longo da progressão referencial, e que, ao mesmo tempo, estimulam o uso de $\mathrm{SNs}$ condizentes com a heterogeneidade semântico-referencial. E essa constatação corrobora o que postulam Mondada e Dubois (2003): o referente, ao longo do discurso, sofre modificações, é revisto, redirecionado, redefinido.

A reflexão sobre os excertos tecida ao longo deste estudo e a análise desenvolvida mostram que, quando o objeto referido é um evento/fato, por vezes, formas verbais diversas contribuem com informações substanciais para a carga semântico-referencial dos SNs. Noutros termos, os valores e pontos de vista que os autores atribuem ao evento - nesse caso, a intercepção sofrida por VCL - são expressos em parte por formas verbais, as 
quais possuem no étimo a carga semântico-referencial de um nome deverbal que expressaria a avaliação/ponto de vista do autor. Exemplo disso

ocorre no excerto 3, em que a forma verbal ter tentado agredir [2] implica denominar a atitude de $\mathrm{CNH}$ como tentativa de agressão.

Recebido em novembro de 2004

Aprovado em fevereiro de 2007

E-mail: miltonchico@yahoo.com.br

\section{REFERÊNCIAS BIBLIOGRÁFICAS}

Koch, I. G. V. e Marcuschi, L. A. 1998. Processo de Referenciação na Produção Discursiva. São Paulo: Revista D.E.L.T.A., 14.Especial: 169-190.

Lyons, J. 1980. Semântica I. Lisboa: Presença/Martins Fontes.

Marcuschi, L. A. e Koch, I. G. V. 2002. Estratégias de referenciação e progressão referencial na língua falada. Gramática do Português Falado - Vol. VIII: Novos estudos descritivos. Campinas: Ed. da Unicamp, Vol.8: $31-56$.

MiLner, J.-C. 2003. Reflexões sobre a referência e a correferência. Tradução de Cavalcante, M. M. In: Cavalcante, M. M.; Rodrigues, B. B. e Ciulla, A. Referenciação. São Paulo: Contexto: 85-130.

Mondada, L. 1997. Processus de catégorisation et construction discursive des catégories. In: Dubors, D. (org.) Catégorisation et cognition: de la perception au discours. Paris: Éditions Kimé: 291-313.

Mondada, L. e Dubois, D. 2003. Construção dos objetos de discurso e categorização: uma abordagem dos processos de referenciação. Tradução de Cavalcante, M. M. In: Cavalcante, M. M; Rodrigues, B. B. e Ciulla, A. Referenciação. São Paulo: Contexto: 17-52.

\section{Corpus analítico}

Drummond I. e Meireles L. 2004. Vanderlei longe da briga. Estado de Minas. Belo Horizonte, 31 ago. Caderno Olimpíadas, p.3.

Geni, R. 2004. Mais do que um susto. Estado de Minas. Belo Horizonte, 30 ago. Caderno Olimpíadas, p.31.

. 2004. Sem título, Estado de Minas. Belo Horizonte, 30 ago. Caderno Olimpíadas - Seção Análise da notícia, p.31.

Irlandês paga fiança e já está solto. Estado de Minas. Belo Horizonte, 31 ago. 2004. Caderno Olimpíadas, p.3. 
Mainardi, R. O irlandês ajudou. Veja, p.147, 08 set. 2004.

Manchete de capa. Isto é. 08 set. 2004.

Recepção de ouro. Estado de Minas. Belo Horizonte, 02 set. 2004, Seção de Esportes, p.29.

Salvador, S. 2004. Sem título. Estado de Minas. Belo Horizonte, 31 ago. Caderno Olimpíadas, p.3.

Vanderlei é exemplo de elegância e superação. Estado de Minas. Belo Horizonte, 30 ago. 2004, Caderno Olimpíadas, p.3. 